\title{
Influence off Biomass Based Carbon Black as Filler Composite on Tensile And Impact Strength
}

\author{
Nurfi Ahmadi ${ }^{1, *}$, Fajar Nugroho $^{2}$ \\ ${ }^{1,2}$ Program Studi Teknik Mesin Sekolah Tinggi Teknologi Adisutjipto \\ Email Korespondensi : "nurfi.ahmadi@yahoo.com
}

Received: 30 September 2019; Accepted : 16 Maret 2020; Published : 1 November 2020

\begin{abstract}
ABSTRAK
Carbon black (CB) yang berasal dari limbah pertanian, batang bambu, tempurung kelapa dan tandan buah sawit diperoleh dengan proses pirolisis dapat digunakan sebagai penguat dalam komposit epoksi. Tujuan dari penelitian ini adalah mengetahui kekuatan tarik dan impak komposit berpenguat carbon black - epoksi. Bahan penguat yang digunakan dalam pembuatan komposit adalah carbon black yang bersumber dari biomassa limbah pertanian. Matrik yang digunakan adalah resin epoksi Baklite EPR 174 dan Epoxy Hardener V-140. Metode pembuatan komposit dengan metode hand lay up. Variasi pengujian dengan menggunakan Fraksi volum carbon black 0, 5, 10, 15, $20 \%$. Selanjutnya akan dilakukan uji tarik, uji impak dan SEM. Kekuatan tarik tertinggi sebesar 44,65 MPa pada 5\% fraksi volume. Kekuatan impak tertinggi sebesar 5,47 MPa pada 5\% fraksi volume. Hasil uji SEM menunjukan distribusi carbon black yang tidak merata pada epoksi, adanya aglomerasi, adanya void dan pull out.
\end{abstract}

Kata kunci : komposit, epoxy, carbon black, kekuatan tarik, kekuatan impak

\section{ABSTRACT}

Carbon blacks (CB), derived from agricultural waste, bamboo stem, coconut shells and oil palm empty fiber bunch, were obtained by pyrolysi used as filler in epoxy composites. The aim of this study was to identify the effect of biomass based carbon black on the tensile and impact strength carbon black - epoxy composite. In this research, carbon black was biomass based. The matrix was epoxy resin Bakelite EPR 174 and epoxy hardener versamid 140 while, the methodology for making the composite was hand lay-up method. The composite were made at 5, 10, 15, 20 volume percentage carbon black then the composite tested with the tensile and impact strength. The highest tensile strength was 44,65 MPa 5 volume percentage carbon black and the highest impact strength was $5.47 \mathrm{MPa}$ volume percentage carbon black. While, based on the result of Scanning Electron Microscope (SEM) analysis showed there were agglomeration at the particle of carbon black, pull out, and void.

Keywords: composite, epoxy resin, carbon black, tensile strength, impact strength

\section{Pengantar}

Material komposit saat ini sudah digunakan secara luas dalam berbagai industri seperti otomotif, kontruksi dan dapat juga digunakan sebagai packaging. Kelebihan material komposit memiliki antara lain sifatnya yang ringan, kekakuan yang bagus, kekuatan thermal dan mekanik yang baik. Saat ini material komposit mengalami perkembangan yang cepat dan banyak didokumentasikan dalam berbagai literatur, namun demikian kajian-kajian fundamental dan penggunaan dari jenis material ini masih sangat menarik untuk dilakukan.

Resin epoksi juga merupakan salah satu jenis matrik polimer yang banyak digunakan karena sifatnya baik seperti kekakuan, kestabilan dimensi dan sifat ketahanan kimia yang baik. Namun demikian sifat mekanik dari matrik dari polimer ini seperti kekuatan, modulus elastisitas, dan ketangguhan dari resin epoksi ini masih belum cukup atau belum memenuhi persyaratan untuk digunakan pada aplikasi tertentu. Oleh karena itu perlu dilakukan modifikasi pada resin polimer agar memenuhi kebutuhan tertentu. Modifikasi untuk memperkuat matrik polimer adalah dengan menambahkan penguat seperti dengan menambahkan, serat sintetis, serat alam maupun penguat berupa partikel.

Salah satu partikel yang bisa digunakan sebagai penguat adalah carbon black. Material ini bisa ditambahkan pada polimer untuk mendapatkan sifat-sifat yang diinginkan dalam komposit yang dibuat. Carbon black di pasaran tersedia dari hasil proses pemecahan termal gas alam dengan proses pembakaran tidak sempurna. Carbon black jenis ini biasanya harganya cukup mahal. Oleh karena itu perlu dilakukan penelitian untuk mengembangkan sumber material carbon black lain dari sumber daya yang mampu terbarukan seperti biomassa dari limbah pertanian. Dari uraian sebelumnya maka perlu dilakukan penelitian 
yang lebih mendalam untuk dapat memanfaatkan limbah pertanian sebagai sumber carbon black sebagai penguat pada komposit bermatrik resin epoksi.

Carbon black mempunyai pengaruh terhadap sifat fisis dan mekanik dari material komposit bermatrik epoksi. Penambahan carbon black dapat memeperbaiki karakteristik material komposit yang dihasilkan untuk dapat diaplikasikan dalam berbagai bidang seperti bahan bipolar, membaran fuel pump dan sebagainya [1,2]. Karakteristik sifat mekanik pada komposit bermatrik epoksi denagan penguat carbon nano tube (CNT) akan sangat ditentukan oleh jumlah partikel CNT yang ditambahankan dalam matrik. Penambahan CNT sebagai penguat ini akan sangat ditentukan juga oleh ukuran dari partikel dan komposisinya. CNT memiliki pengaruh yang optimal sampai pada komposisi jumlah tertentu kemudian akan mengalami kejenuhan bila jumlah CNT yang ditambahkan semakin banyak $[1,3,5]$.

Sifat mekanik pada komposit CNT-Epoksi juga sangat dipengaruhi oleh proses pembuatannya dari komposit tersebut. Perlakuan pada saat pengadukan, penuangan dan setelah penuangan dalam cetakan sangat menentukan sifat mekanis yang dihasilkan. Pelakuan postcuring dengan menggunakan pemanas dapat mengurangi jumlah void serta dapat meningkatkan kekuatan mekanik komposit CNT-Epoksi jika dibandingkan dengan cara konvensional yang tanpa dilakukan pemanasan $[3,4,5]$.

Pada proses fabrikasi nano komposit CNT-Epoksi yang baik akan megurangi adanya cacat seperti munculnya void, maupun penggumpalan partikel. Adanya void dan penggumpalan partikel CNT akan menyebabkan distribusi tegangan pada komposit menjadi tidak merata. Aglomerasi juga berpeluang menyebabkan adanya konsentrasi tegangan yang sangat berpengaruh terhadap sifat fisis maupun mekanis komposit CNT-Epoksi. Penambahan CNT dengan jumlah yang semakin besar pada hasil SEM menunjukan adanya potensi terjadinya penggumpalan pada matrik epoksi $[2,4,6,8]$.

\section{Metodologi Penelitian}

Dalam penelitian ini, komposit dibuat dengan menggunakan metode Hand lay-up atau pencetakan terbuka yang sesuai untuk membuat berbagai macam produk komposit dari sangat kecil hingga sangat besar. Hand lay-up biasanya disertai dengan tekanan yang diterapkan untuk memadatkan material untuk menghilangkan udara yang terperangkap. Volume produksi per cetakan rendah, Namun dapat menghasilkan jumlah produksi yang besar dengan menggunakan banyak cetakan. Hand lay-up adalah metode pencetakan komposit yang paling sederhana, menggunakan peralatan dengan biaya rendah, pemrosesan sederhana dengan berbagai ukuran bagian. Perubahan desain mudah dilakukan. Ada investasi minimal pada peralatan. Dengan operator yang terampil, dan proses yang baik maka akan diperoleh komposit dengan hasil yang baik.

Pengujan tarik bertujuan untuk mengetahui tegangan, regangan, modulus elastisitas bahan dengan cara menarik spesimen sampai putus. Pengujian tarik dilakukan dengan mesin menurut standar ASTM D 638 uji tarik atau dengan Universal Testing Standard.

Tujuan dilakukanya penelitian uji impact untuk mengetahui seberapa besar penyerapan energi potensial yang dihasilkan dari pendulum yang diayunkan dari ketinggian kemudian secara tiba tiba menumbuk benda uji sehingga benda uji mengaalami deformasi. Untuk melakukan uji impak, telah ditentukan bahwa standart tes yang dilakukan adalah standart ASTM D 5942-96 dengan tebal minimal 3,6 $\mathrm{mm}$.

Pengamatan morfologi ini dilakukan dengan menggunakan Scanning Electron Microscope. Alat Scanning Electron Microscope (SEM) Untuk pengamatan menggunakan SEM dilakukan untuk mengetahui morfologi. Pengambilan gambar SEM dengan perbesaran 100-1500 kali. Dengan menggunakan SEM. Pengamatan struktur mikro menggunakan SEM, prinsipnya adalah dengan menembakan sampel dengan menggunakan elektron, dan nantinya pantulan elektron dari tumbukan dengan sampel tadi akan ditangkap oleh detektor-detektor yang kemudian dapat menampilkan gambar struktur mikro pada monitor

\section{Hasil dan Pembahasan}

\subsection{Hasil Uji Tarik.}

Hasil uji tarik pada komposit yang telah dibuat dapat dilihat pada Gambar 1 yang menunjukan hasil uji tarik komposit dengan penguat carbon black (CB) terhadap variasi fraksi volume. Penambahan CB terhadap resin epoksi berpengaruh terhadap kekuatan tarik komposit yang dihasilkan. Komposit dengan penambahan CB sebesar 5\% $\left(\mathrm{Vol}_{\mathrm{cb}}\right)$ memiliki kekuatan tarik sebesar 53,65 $\mathrm{MPa}$, penambahan CB sebesar $10 \%\left(\mathrm{Vol}_{\mathrm{cb}}\right)$ memiliki kekuatan tarik sebesar 37,24 MPa, penambahan CB sebesar 15\% ( $\left.\mathrm{Vol}_{\mathrm{cb}}\right)$ memiliki kekuatan tarik sebesar 32,77 MPa dan penambahan CB sebesar 20\% ( Vol $\left._{\mathrm{cb}}\right)$ memiliki kekuatan tarik sebesar 28,3 $\mathrm{MPa}$. Gambar 4.1 juga memberikan informasi bahwa kekuatan tarik tertinggi adalah pada penambahan CB sebesar $5 \%\left(\mathrm{Vol}_{\mathrm{cb}}\right)$ dan kekuatan tarik terendah adalah pada penambahan $\mathrm{CB}$ sebesar $20 \%\left(\mathrm{Vol}_{\mathrm{cb}}\right)$. 


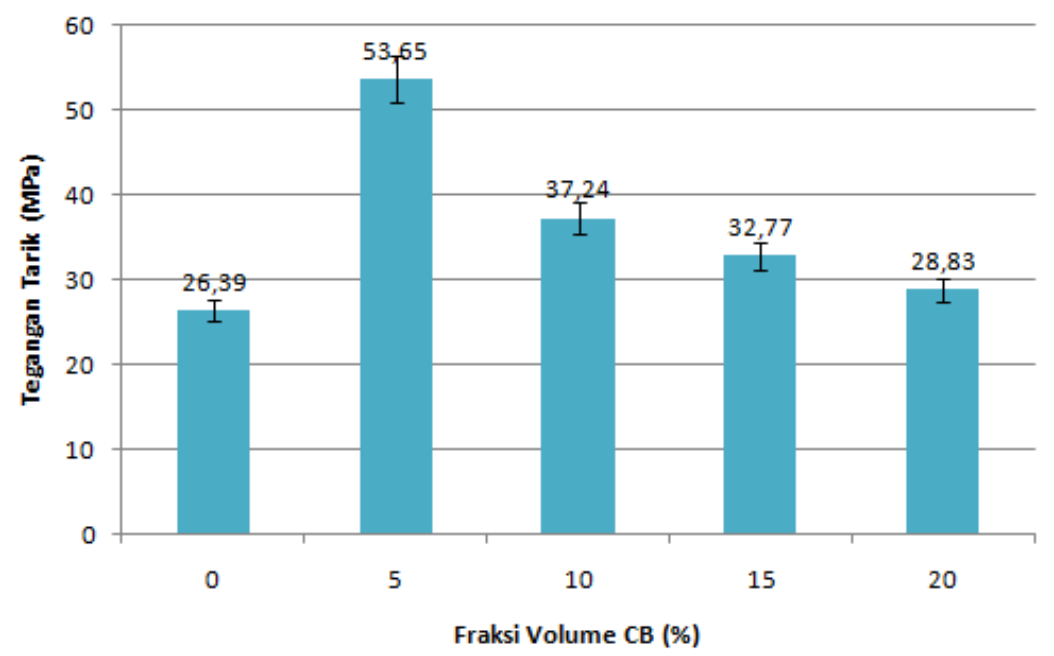

Gambar 1. Grafik Kekuatan Tarik vs Fraksi Volume CB

Namun bila dibandingkan dengan kekuatan tarik material 100\% resin epoksi maka penambahan CB menyebabkan kenaikan kekuatan tariknya. Peningkatan kekuatan tarik ini tidak menunjukan kecenderungan yang linear. Hal ini bisa dilihat dari nilai kekuata tarik komposit cenderung menurun dengan adanya penambahan $\mathrm{CB}$ di atas $5 \%\left(\mathrm{Vol}_{\mathrm{cb}}\right)$. Penambahan $\mathrm{CB}$ dalam jumlah yang semakin besar akan menyebabkan terjadinya aglomerasi partikel CB serta sebaran distribusi partikel CB yang tidak merata. Kekuatan komposit akan sangat ditentukan oleh ikatan antar muka komponen penyusun komposit. Aglomerasi menyebabkan luas permukaan yang berikatan akan semakin kecil jika dibandingkan jika partikel CB terdistribusi secara merata dalam matrik. Dengan demikian ikatan antara matrik epoksi dan CB lemah dan menyebabkan menurunnya kekuatan tarik komposit CB-epoksi.

\subsection{Hasil Uji Impak.}

Hasil uji impak pada komposit yang telah dibuat dapat dilihat pada Gambar 2 berikut ini.

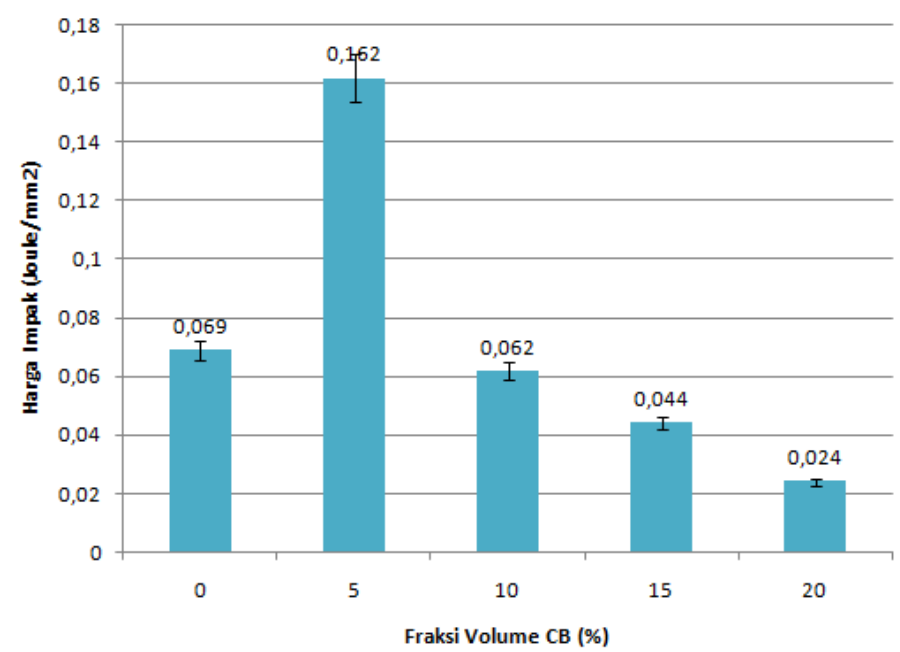

Gambar 2. Grafik Harga Impak vs Fraksi Volume CB $\left(\% \mathrm{Vol}_{\mathrm{cb}}\right)$

Gambar 2 menunjukan kecenderungan pengaruh variasi penambahan CB pada resin epoksi. Penambahan CB terhadap resin epoksi berpengaruh terhadap kekuatan impak komposit yang dihasilkan. Komposit dengan penambahan $\mathrm{CB}$ sebesar $5 \%\left(\mathrm{Vol}_{\mathrm{cb}}\right)$ memiliki kekuatan impak sebesar 0,162 J/mm2, penambahan $\mathrm{CB}$ sebesar $10 \%\left(\mathrm{Vol}_{\mathrm{cb}}\right)$ memiliki kekuatan impak sebesar 0,62 J/mm2, penambahan $\mathrm{CB}$ sebesar $15 \%\left(\mathrm{Vol}_{\mathrm{cb}}\right)$ memiliki kekuatan impaksebesar $0,044 \mathrm{~J} / \mathrm{mm} 2$ dan penambahan $\mathrm{CB}$ sebesar $20 \%$ $\left(\mathrm{Vol}_{\mathrm{cb}}\right)$ memiliki kekuatan impak sebesar 0,024 J/mm2. Gambar 2 juga memberikan informasi bahwa kekuatan tarik tertinggi adalah pada penambahan $\mathrm{CB}$ sebesar $5 \%\left(\mathrm{Vol}_{\mathrm{cb}}\right)$ dan kekuatan tarik terendah adalah pada penambahan $\mathrm{CB}$ sebesar $20 \%\left(\mathrm{Vol}_{\mathrm{cb}}\right)$. 
Secara keseluruhan penambahan CB dalam resin epoksi memberikan pengaruh yang cukup baik terhadap kekuatan impak. Namun demikian pengaruh yang dihasilkan menurun untuk variasi $10 \%, 15 \%$ dan $20 \%$ fraksi volume CB. Penurunan harga impak pada penambahan CB sebesar $15 \%$ dan $20 \%$ justru harga impaknya dibawah resin epoksi tanpa penambahan CB. Semakin besar jumlah CB yang ditambahkan maka kemungkinan terjadi aglomerasi akan semakin besar. Distribusi CB yang tidak merata akan menyebabkan adanya konsentrasi tegangan pada material komposit. Uji impak merupakan jenis pengujian yang sensitif terhadap adanya suatu konsentrasi tegangan. Selain faktor konsentrasi tegangan harga impak yang rendah juga disebabkan oleh meningkatnya penyerapan (absobsi) kadar air. Faktor absorbsi kadar air ini bisa terjadi pada bahan CB dan selama proses pengeringan komposit CB-epoksi.

Kemampuan menyerap energi tumbukan pada komposit CB-Epoksi akan sangat dipengaruhi oleh ikatan antar muka CB dan resin epoksi, serta sensivitas komposit CB-epoksi terhadap perambatan retak. Aglomerasi menyebabkan distribusi $\mathrm{CB}$ pada matrik tidak merata sehingga ikatan antar muka (surface bonding) menjadi lemah. Surface bonding yang lemah menyebabkan meningkatnya sensivitas terhadap perambatan retak terutama pada saat menerima beban kejut. Dengan penambahan CB yang semakin besar maka viscositas matrik akan semakin meningkat dengan demikian distribusi CB dalam matrik epoksi semakin tidak merata. Ketika komposit CB-Epoksi menerima beban kejut maka beban akan terkonsentrasi pada titik terlemah dan perambatan retak akan berjalan secara cepat. Adanya rongga dan bahan penguat yang tidak terikat dengan baik dengan matrik dapat mempengaruhi terhadap kekuatan impak [5, 6, 7].

\subsection{Hasil Uji SEM}

Partikel CB yang terdistribusi dengan baik akan menyebabkan lintasan perambatan retak akan semakin panjang. Retakan yang terjadi akibat beban tumbukan akan diserap dan dilokalisir oleh partikel CB kemudian diteruskan atau dibelokan arahnya. Dengan demikian jika distribusi partikel CB dapat merata maka lintasan perambatan retak juga akan semakin panjang sehingga kekuatan impak akan semakin tinggi. Gambar 3 merupakan hasil Uji SEM pada patahan spesimen uji tarik komposit CB-Epoksi dengan 5\% Fraksi Volume $\left(\% \mathrm{~V}_{\mathrm{cb}}\right)$.

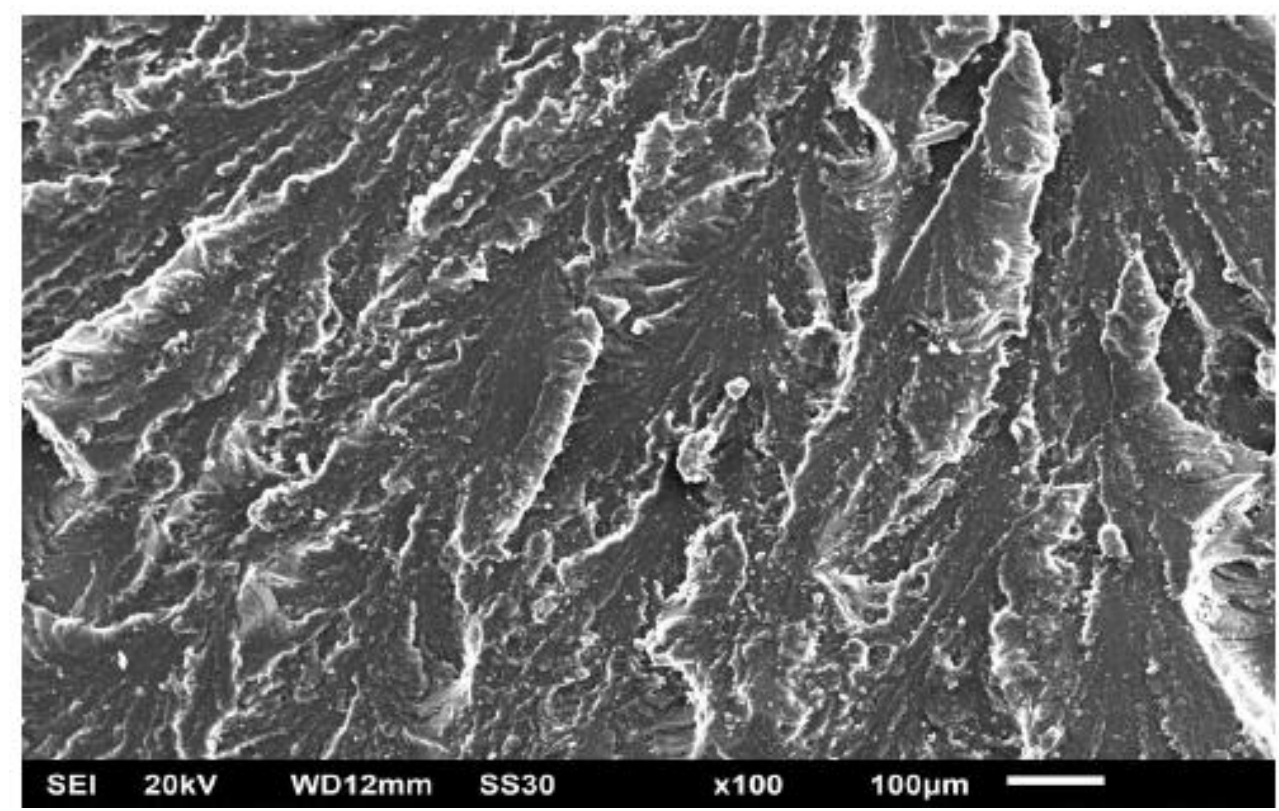

Gambar 3 Foto SEM patahan Komposit CB-Epoksi 5\% Vol cb $_{\text {. }}$

Gambar 3 menunjukan adanya pola patahan getas pada material komposit CB- Epoksi. Regangan yang terjadi pada spesimen uji tarik juga rendah. Morfologi permukaan patahan ini juga menunujukan adanya perambatan retak di sekitar butiran CB (cleavage). Rongga-rongga kosong yang terjadi pada komposit yang dihasilkan disebabkan oleh perbedaan ukuran butiran serbuk CB. Jumlah porositas meningkat saat dilakukan proses pencetakan dengan metode hand lay-up yang tidak diikuti dengan proses vakum. 


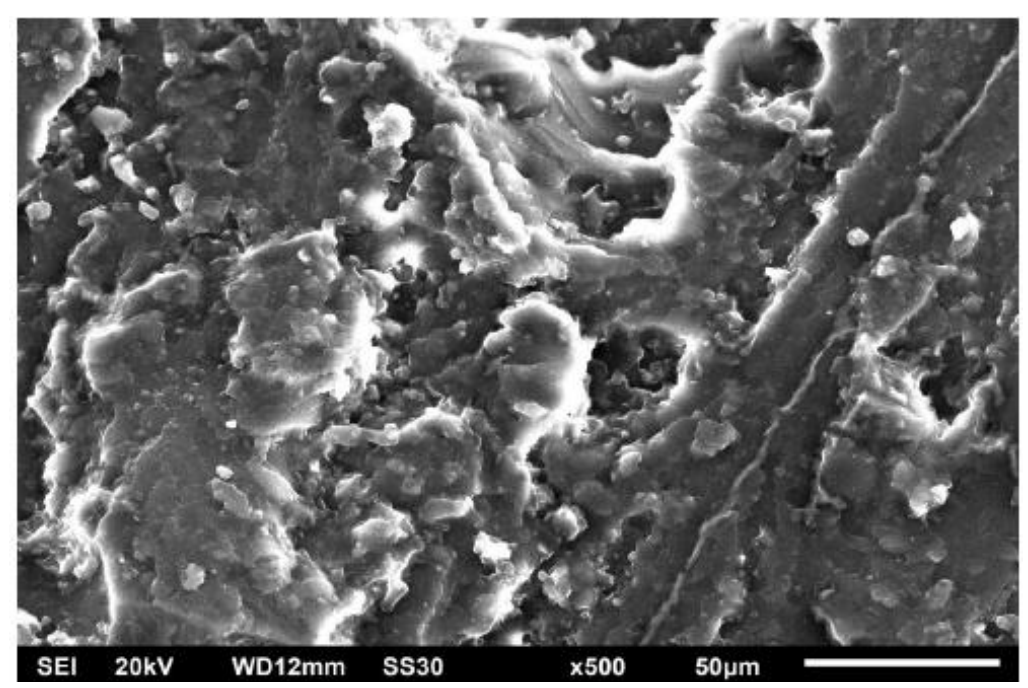

Gambar 4. Foto SEM porositas komposit CB-Epoksi 5\% Vol $\mathrm{Cb}_{\mathrm{cb}}$

Porositas pada komposit bisa sebabkan oleh beberapa faktor seperti viskositas yang tinggi, perbedaan densitas filler dan matrik, dan material filler yang bersifat higroskopis. Viskositas yang tinggi akan menyebabkan campuran antara matrik dan penguat akan sulit dicetak karena sifat mampu alir (fluiditas) rendah. Perbedaan densitas akan menyebabkan distribusi filler tidak merata dalam matrik dan kecenderungan terjadinya aglomerasi sangat besar. Hal ini juga akan meyebabkan terjadinya void yang banyak. Material yang bersumber dari alam seperti biomassa biasanya memiliki kecenderungan sifat higroskopis yang tinggi, sangat mudah menyerap uap air dari lingkungan sekitarnya. Kandungan uap air yang terdapat dalam filler CB akan menyebabkan gelembung udara yang pada akhirnya menyebabkan terjadinya void. Kandungan uap air dalam filler juga akan menyebabkan ikatan antar muka antara CB dan epoksi menjadi tidak sempurna.

Void pada komposit sangat berpengaruh terhadap ikatan antara partikel CB dan matrik epoksi. Void terjadi karena adanya celah pada partikel dan bentuk partikel CB yang tidak sempurna. Adanya void akan mengurangi kekuatan komposit. Semakin banyak void maka akan semakin lemah kekuatan mekanik komposit yang dihasilkan. Hal ini terjadi karena luasan bidang yang menahan beban berkurang serta ikatan antar muka penyusun komposit juga menjadi lemah.

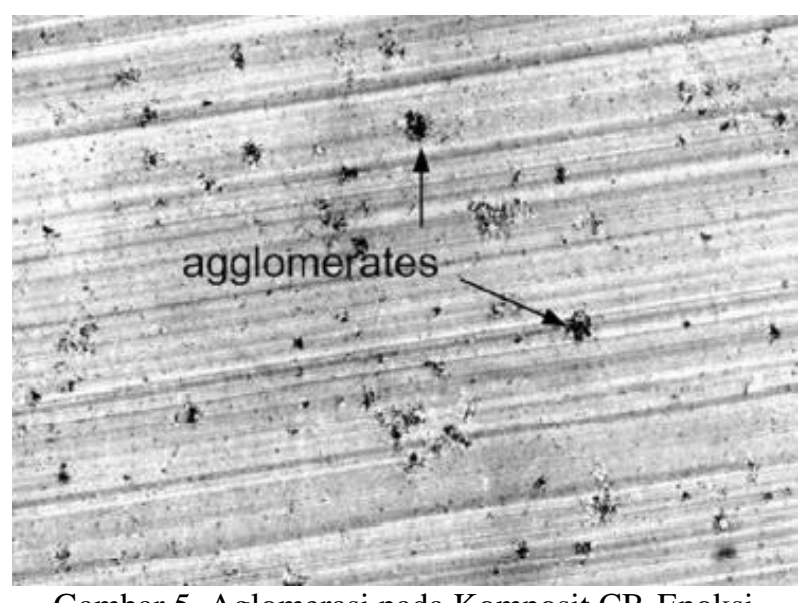

Gambar 5. Aglomerasi pada Komposit CB-Epoksi

Dari Gambar 5 dapat dilihat adanya aglomerasi serbuk partikel CB dalam matrik epoksi. Aglomerasi tersebut akan menyebabkan kekuatan mekanis seperti kekuatan tarik dan kekuatan impak akan menurun. Gumpalan CB pada komposit menyebabkan distribusi tegangan tidak merata, serta menyebabkan luasan permukaan yang berikatan semakin sedikit [8,9]. Aglomerasi juga akan menyebabkan adanya konsentrasi tegangan dalam komposit [10]. Hal ini akan mempengaruhi lintasan perambatan retak sehingga komposit lebih sensisitif terhadap beban kejut. 


\section{Kesimpulan}

Penambahan CB sampai pada jumlah tertentu akan meningkatkan kekuatan tarik dam impak komposit CB-epoksi. Kekuatan tarik tertinggi dicapai pada penambahan CB 5\% fraksi volume. Sedang untuk $\mathrm{CB}$ di atas 5\% kekuatan tarik dari komposit akan menurun. Kekuatan impak komposit CB- Epoksi juga menunjukan nilai tertinggi pada penambahan $\mathrm{CB}$ hingga 5\% fraksi volume. Hasil uji SEM menunjukan distribusi CB yang tidak merata pada epoksi, adanya aglomerasi, adanya void dan pull out.

\section{Daftar Pustaka}

[1] Rizkyta, A. G., \& Ardhyananta, H, "Pengaruh Penambahan Karbon terhadap Sifat Mekanik dan Konduktivitas Listrik Komposit Karbon/Epoksi Sebagai Pelat Bipolar Polimer Elektrolit Membran Sel Bahan Bakar (Polymer Exchange Membran (PEMFC))", Jurnal Teknik ITS, 2(1), F36-F40, 2013

[2] Cha, J., Jin, S., Shim, J. H., Park, C. S., Ryu, H. J., \& Hong, S. H., "Functionalization of Carbon Nanotubes for Fabrication of CNT/Epoxy Nanocomposites", Materials \& Design, 95, 1-,2016

[3] Sung, P. C., Chiu, T. H., \& Chang, S. C, "Microwave curing of carbon nanotube/epoxy adhesives", Composites science and technology, 104, 97-103, 2014

[4] Guadagno, L., Vertuccio, L., Sorrentino, A., Raimondo, M., Naddeo, C., Vittoria, V., ... \& Russo, S., "Mechanical and Barrier Properties of Epoxy Resin Filled With Multi-Walled Carbon Nanotubes", Carbon, 47(10), 2419-2430, 2009

[5] Wernik, J. M., \& Meguid, S. A., "On The Mechanical Characterization Of Carbon Nanotube Reinforced Epoxy Adhesives”, Materials \& Design, 59, 19-32, 2014

[6] Khalil, H. A., Firoozian, P., Bakare, I. O., Akil, H. M., \& Noor, A. M.,’Exploring Biomass Based Carbon Black As Filler In Epoxy Composites: Flexural And Thermal Properties", Materials \& Design, 31(7), 3419-3425, 2010

[7] Leman, Z., Sapuan, S. M., Saifol, A. M., Maleque, M. A., \& Ahmad, M. M. H. M., "Moisture Absorption Behavior Of Sugar Palm Fiber Reinforced Epoxy Composites", Materials \& Design, 29(8), 1666-1670, 2008

[8] McIntyre, S., Kaltzakorta, I., Liggat, J. J., Pethrick, R. A., \& Rhoney, I., "Influence Of The Epoxy Structure On The Physical Properties Of Epoxy Resin Nanocomposites", Industrial \& engineering chemistry research, 44(23), 8573-8579, 2005

[9] Sui, G., Zhong, W. H., Liu, M. C., \& Wu, P. H., "Enhancing Mechanical Properties Of An Epoxy Resin Using "Liquid Nano-Reinforcements"”. Materials Science and Engineering: A, 512(1-2), 139142, 2009

[10] F. Nugroho, "Pengaruh Kandungan Partikel Serbuk Genteng Sokka Terhadap Kekuatan Tarik Dan Kekuatan Impak Pada Komposit Bermatriks Epoxy," Conference SENATIK STT Adisutjipto Yogyakarta, vol. 3, Dec. 2017. 